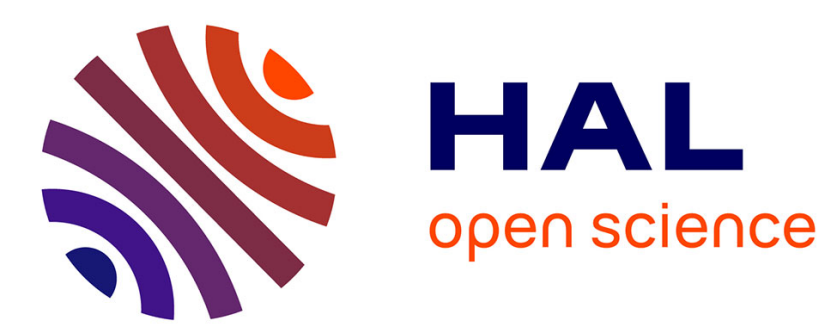

\title{
Comparative responses of spiders and plants to maritime heathland restoration
}

Axel Hacala, Maxime Le Roy, Jerome Sawtschuk, Julien Pétillon

\section{To cite this version:}

Axel Hacala, Maxime Le Roy, Jerome Sawtschuk, Julien Pétillon. Comparative responses of spiders and plants to maritime heathland restoration. Biodiversity and Conservation, 2020, 29 (1), pp.229-249. 10.1007/s10531-019-01880-y . hal-02355338

\section{HAL Id: hal-02355338 \\ https://hal-univ-rennes1.archives-ouvertes.fr/hal-02355338}

Submitted on 3 Feb 2020

HAL is a multi-disciplinary open access archive for the deposit and dissemination of scientific research documents, whether they are published or not. The documents may come from teaching and research institutions in France or abroad, or from public or private research centers.
L'archive ouverte pluridisciplinaire HAL, est destinée au dépôt et à la diffusion de documents scientifiques de niveau recherche, publiés ou non, émanant des établissements d'enseignement et de recherche français ou étrangers, des laboratoires publics ou privés. 
4 Axel Hacala ${ }^{1,2, £}$, Maxime Le Roy ${ }^{1}$, Jérôme Sawtschuk ${ }^{1} \&$ Julien Pétillon $^{2}$

5

$6{ }^{1}$ EA Géoarchitecture: Territoires, Urbanisation, Biodiversité, Environnement, Université de

7 Bretagne Occidentale, CS 93837, 29238 Brest cedex 3, France

$8{ }^{2}$ UMR CNRS 6553 Ecobio, Université de Rennes, 263 Avenue du Gal Leclerc, CS 74205,

935042 Rennes cedex, France

10 £: Corresponding author; Tel: +336 165076 52, Email: axel.hacala@ gmail.com 
Assessment of habitat restoration often rely on single-taxa approach, plants being widely used.

13

Arthropods might yet complement such evaluation, especially in hard, poorly-diversified environments such as maritime clifftops. In this study we compared the responses of spiders and plants (both at species and assemblage levels) to increasing time of heathland restoration. Sampling took place in different sites of Brittany (Western France), using a replicated design of both pitfall traps and phytosociological relevés. A total of 5056 spiders belonging to 160 species, and 103 plant species were found. No change in species richness between degradation states was found for spiders. Plant species richness was lower in highly degraded habitats of recently restored sites but was not in the oldest restored one. Species composition greatly changed through turnover mechanisms between all sites and degradation states, for both spider and vegetation. Heterogeneity was higher in references states, and increased over restoration time between sites. The number of indicator species decreased with restoration age for spiders, while no indicator species was found for plants. Restoration is still on-going after 15 years, with no recovery of reference assemblages for both plants and spiders, but there were some signals toward reference in the oldest restoration site. Plants and spiders were proved to be complementary bio-indicators of post disturbance restoration, as they bring different, scaledependent information on restoration success.

Key-words: Indicator taxa, species turn-over, Araneae, Ulex, Brittany, clifftop. 


\section{Introduction}

33 Due to strong environmental stresses (mainly wind and salt deposition: Malloch 1972; Sawtschuk 2010), maritime clifftops present particular conditions for flora and fauna, which lead to the establishment of maritime heathlands, a habitat protected by European legislation Natura 2000 (Sawtschuk et al. 2010), under the codes 4030 (European dry heaths) and 4040 (dry Atlantic coastal heaths with Erica vagans). Despite their high conservation values, maritime clifftops are often degraded along the French East-Atlantic coasts because of important touristic uses, leading to intensive human trampling and/or building constructions (especially since the 50s: Le Fur 2013; Sawtschuk 2010). These habitats have actively been restored since the 90s, first for landscape and then for biodiversity purposes (Le Fur 2013), locally resulting in sites with different state of degradation. In Brittany (Western France), most of restoration projects include passive restoration by precluding areas from human trampling or vehicle access. Some projects also use active restoration methods (e.g. biodegradable geotextile and fascines use) to initiate or accelerate the restoration of degraded sites. Some projects finally include the deconstruction of infrastructures such as building or car parks, together with public access restriction. Since the start of the restoration projects (between 2002 and 2012 for our study sites) vegetation monitoring plots are set up to assess the efficiency of restoration practises (Desdoigts 2000, Le Roy et al. 2019). This has proven that passive restoration, when performed in moderately or lightly degraded areas, is usually enough to create a good restoration dynamic (Sawtschuk et al. 2010). However, this assessment of ecological restoration success mainly relies on vegetation analysis. To the best of our knowledge, no study has been performed to assess the restoration of arthropod assemblages in degraded maritime heathlands yet.

Measurements of species diversity and abundance constitute the most widely used indicator of restoration success (Wortley et al. 2013), mainly using plants as bio-indicators ( Morrison 1998; 
Babin-Fenske \& Anand 2010; Kollmann et al. 2016). There are different reasons to explain this over-representation of plants, such as the facility to sample this group (Gatica-Saavedra et al. 2017) or the lesser impact of seasonality on plant assemblages compared to animal assemblages (Ruiz-Jaen \& Aide 2005). Some authors also claimed that restoration of indigenous plants might naturally lead to the restoration of fauna (Young 2000), because of their structural and functional roles (Allen 1998). Fauna and more specifically arthropods are comparatively less used as bio-indicators (Ruiz-Jaen \& Aide 2005; Wortley et al. 2013), while they represent more diversified taxonomic and functional groups (Longcore 2003). Using vegetation only as a proxy of global restoration success is thus increasingly criticised in literature (Morrison 1998; Andersen Majer 2004). Arthropods are known to answer differently to restoration (BabinFenske \& Anand 2010; Feest et al. 2011; Spake et al. 2016), and can actually complement assessments only based on plants (Pétillon et al. 2014). Arthropods are yet under-studied, probably because of their complexity and the specific skills required to identify some taxa (Gerlach et al. 2013). To encourage the use of arthropods in monitoring projects, some authors therefore recommended using bio-indicator taxa instead of the whole arthropod assemblage ( Longcore 2003; Pearce \& Venier 2006; Gerlach et al. 2013). Monitoring arthropod taxa is thus expected to complete conclusions based on vegetation studies, especially in habitats where specific abiotic conditions lead to specific arthropod assemblages (Leibold et al. 2004; Schirmel et al. 2012). Such taxa have to fulfil a number of criteria to be considered as "good" bioindicators: nor too rare nor too common, to contain specialised taxa (e.g. by habitat, feeding regime, etc.: Caro \& O’Doherty 1999), and easy to sample and to identify. Spiders, dominant arthropod predators in many terrestrial habitats, are one of these taxa described as good bioindicators (Cristofoli et al. 2010; Gerlach et al. 2013; Ossamy et al. 2016), and also reported to react fast and differently from plants to local habitat disturbance (Lafage et al. 2019). In maritime grasslands and maritime heathlands, extreme conditions such as nutrient-limited and 
shallow soil (Bourlet 1980), high wind exposure and salt deposit (Malloch 1972; Sawtschuk 2010) lead to specific plant assemblages (Bioret \& Géhu 2008). The same probably applies for arthropods that have to resist, and likely to be adapted, to these strong constraints.

In this study we assess the complementarity of plants and arthropods to monitor the restoration success of degraded maritime heathlands by comparing their patterns in taxonomic diversity (both alpha and beta, i.e. functional and rarity based metrics were not considered here, see e.g. Leroy et al. 2014). We first tested the hypothesis that reference habitats host few but constant specialist species, while degraded habitat host as many, but more context-dependent, generalist or opportunistic species and that their ratio is driven by the intensity of degradation (figure 1). We consequently expect (i) species richness to be similar between degradation states, (ii) species composition to differ between sites, with heterogeneity of assemblages (estimated by $\beta$-diversity) increasing with restoration process due to higher species turnover and a constant nestedness (i.e. species pool in degraded habitats is not a subset of species pool in reference habitat: see Baselga 2010) and (iii) a decreasing number of indicator species explained by a higher degradation. Although environmental filters act differently on plants and spiders (see e.g. Klejin et al. 2006), we do not expect significant differences in alpha- and beta-diversity patterns between these taxa (see e.g. Lafage et al. 2015). The number of indicators species in degraded states is expected to increase with time since restoration for both taxa (because pools of generalist species are larger and more site-dependent), while this number should remain constant in reference states. Lastly, we expect more indicator species for plants than for spiders, the latter being more mobile and thus more likely to be found in different adjacent degradation states. 
Study sites and sampling design

107 Fieldwork was done in three coastal sites of Brittany, Western France (Appendix 1). Sites were 108 coded using the time (in years) since their restoration (at the time of fieldwork, i.e. 2017). L'Apothicairerie (S5) (47²1'44.0" N, 315'34.9" W) was heavily degraded by infrastructures (mainly car park and hotel) that were removed in 2012. La Pointe de l'Enfer (S11) $\left(47^{\circ} 37^{\prime} 18.3^{\prime \prime} \mathrm{N} 3^{\circ} 27^{\prime} 46.9^{\prime \prime} \mathrm{W}\right)$ was degraded by human trampling and by frequent vehicle access. Both degradations sources were removed from the site in 2006. The last site La Pointe de Pen113 Hir (S15), located on the mainland $\left(48^{\circ} 15^{\prime} 03^{\prime \prime} \mathrm{N}, 4^{\circ} 37^{\prime} 25^{\prime \prime} \mathrm{W}\right)$, was mainly degraded by human trampling that was reduced in 2002. Therefore S5 is the youngest restoration site with five years of restoration while S15 has the longest restoration time. These sites were selected because of their increasing age of restoration, but also because they all present the same kind of reference vegetation (i.e. without degradation) which is a short and dry heathland dominated by Erica spp. and Ulex spp. (Appendix 1).

On top of the reference (further abbreviated RF) state, two other states were defined according to their morphology and selected at each site: heavily damaged (HD) and moderately damaged

121 (MD). Two $400 \mathrm{~m}^{2}$ plots of homogeneous vegetation were designed for each degradation state, and four pitfall traps (80mm in diameters and 100mm deep) were set at each plot. Traps were half-filled of salted solution (250 g.L $\left.\mathrm{L}^{-1}\right)$ with a drop of odorless soap and settled 10 meters apart in order to avoid interference and local pseudoreplication (Topping and Sunderland, 1992). This resulted in 71 traps (in one station, the sampling area was too restricted to set 4 traps spaced of

$12610 \mathrm{~m}$ apart, so 1 was removed) active between mid-March to mid-June 2017, and emptied every two weeks. Total plant cover was estimated in a $5 \mathrm{~m}$ radius circle around every trap, and all species were identified and their percentage cover estimated. Pitfall samples were sorted, arthropods transferred to ethanol $70^{\circ}$, and stored at the University of Rennes 1 . Spiders were 
130 identified to species level using keys of Roberts (1985) and Nentwig (2019). Data were pooled

131 together by state of degradation and by site.

132 Data analysis

133 Spider and plant assemblages were consistently analyzed by (1) comparing alpha and beta134 diversities between sites and between degradation states within sites, and (2) looking for 135 indicator taxa of specific degradation states. Sampling coverage curves were computed 136 (Appendix 2), and the above 90\% values used to check the validity of the sampling protocol, 137 and to assess the overall quality of spider and plant datasets. Site effect was tested through 138 assemblage composition analysis (Anosim), which further determined whether sites were 139 grouped or not in subsequent analyses.

140 We compared alpha-diversity (species richness) between states using estimated richness based 141 on the methods developed by Chao $(1984,1987)$. The "iNEXT" function from iNEXT package 142 (Chaos et al. 2014). This method was selected to account for possible influence of sampling 143 coverage. The test was ran with 40 knots and 200 bootstrap replication. Significant differences 144 were assessed through the absence of overlapping confidence intervals on iNEXT curves (Chao 145 et al. 2014).

146 Assemblages were compared between sites using NMDS with a Sørensen dissimilarity matrix 147 that is not affected by joint absence (Borcard et al. 2011). Data was transformed to 148 presence/absence data to avoid abundance bias from difference in species activity rate and/or 149 in sensitivity to environment structures (Lang 2000). If ANOSIMs were significant, subsequent 150 analyses on beta-diversity and indicator species were performed site by site, if not sites were 151 pooled together for comparing degradation states.

152 Beta-diversities were compared using NMDS and ANOSIM on dissimilarity matrices to 153 identify significant differences between assemblages. NMDS and ANOSIM tests were 
154 performed using "MetaMDS" and "anosim" functions of the "vegan" package (Oksanen et al. 155 2019) respectively. When ANOSIMs were performed on pairs of states, level of significance 156 was adjusted using correction (here $\alpha=0.016$ ). Dissimilarity matrices were calculated with the

157 Sørensen dissimilarity on presence/absence data with the "beta.pair" function ("betapart" 158 package, Baselga et al. 2018). This method assesses for broad dissimilarity and its partition 159 following Baselga (2012). Between-site dissimilarity was calculated to assess beta diversity 160 patterns (Baselga 2010) within degradation states using the "beta.multi" function ("betapart" 161 package, Baselga et al. 2018).

162 IndVal were calculated using presence absence data (Dufrêne \& Legendre 1997) in order to 163 identify the species representative of each state in terms of fidelity and exclusivity. Significance 164 of IndVal was tested using a random reallocation procedure with 1000 permutations using the 165 "indval" function from "labdsv" package (Roberts 2016). Only taxa both with an IndVal > 0.5 166 and with a significant p-value were considered accurate indicators of their respective 167 degradation state (Pétillon et al. 2010).

168 All analyses were carried out using R software (version 3.2.3 2015/12/10).

\section{Results}

1705056 adult spiders belonging to 160 species were identified (Appendix 3). The most common 171 species were Pardosa monticola (1458 individuals) and Pardosa nigriceps (599 individuals). 172 A total of 133 plant species were identified (Appendix 4). The most common species were 173 Leontodon saxatilis ssp. saxatilis and Plantago coronopus, both found in more than $60 \%$ of 174 sampled plots. Festuca ovina, Calluna vulgaris and Agrostis stolonifera were also found in the 175 three sites, and were found in more than $10 \%$ of plots. 
178 Spider estimated richness showed no significant pattern between degradation states (Figure 2).

179 No statistical differences were found in estimated species richness of spiders, with all 180 confidence intervals overlapping. Plant assemblages showed a lower richness in the most 181 degraded state for both S5 and S11 sites. The oldest restoration site (S15) showed no significant 182 differences in plant species richness between the three states.

Assemblage composition

185

Both taxa significantly differed in their assemblage composition between sites (ANOSIM on presence / absence data, spider: $\mathrm{R}=.76, \mathrm{P}=0.001$; plants: $\mathrm{R}=.69, \mathrm{P}=0.001$, Figure 3 ), which can be explained by important differences in species occurrence. S5 was the spider richer site with 112 different species, half were found only in this site (Figure 3). Out of the 81 species identified in S11, a third was unique to this site. S15 was the less spider diversified site (57 species), and a fifth of these was found only there. The same pattern was found for plant assemblages (Figure 3). Site $S 5$ was indeed the most diversified site (63 species), followed by $S 11$ (48 species) and S15 (39 species), with only 15 species common to the three sites. Half of S5 and S11 plant species were found only on these sites, whereas a quarter of S15 species was unique to this site. Sites were finally ordered by geographic proximity, for both spider and plant assemblages, and total species richness of sites increased from North to South. Because of such strong differences between assemblages of the three studied sites, further analyses on beta-diversities and indicator species were done site by site.

RF states had the highest beta-diversities, while degraded states had similar, lower, betadiversities (Table 1). Patterns in beta-diversities were driven by changes in turn-over, while nestedness was negligible. NMDS displayed results consistent with beta-diversity analyses 
201 (Appendix 5), i.e. higher heterogeneity in RF sites. An overlap in species assemblages in the 202 oldest restoration site was finally observed for both plants and spiders (although while spider

203

204

205

206

207

208

209

210

211

212

213

214

215

216

217 assemblages between MD and HD in S15 seem closer, they still differ significantly: ANOSIM, $\mathrm{R}=0.17, \mathrm{P}=0.04)$.

Indicator taxa

Several significant indicator taxa above the $0.5 \mathrm{IndVal}$ value threshold were found for spiders (Table 2). They were no spider indicator of reference state in S5, 9 in S11 and 1 in S15. Mildly degraded states had 14 indicator spider species in S5, 2 in S11 and 0 in S15. Highly degraded had 4 indicator spider species in S5, 1 in S11 and 0 in S15 (see appendix 3 for species list). There was no significant indicator plant species, i.e. having an IndVal above the 0.5 threshold.

\section{Discussion}

Species richness

Contrary to other studies reporting that species richness follows perturbation or degradation patterns (Varet et al. 2013, Bargmann et al. 2015), species richness remained stable for spider assemblages. This is overall consistent with Bell et al. (1998) who described species richness a quite unreliable metrics for monitoring management effects. Plants responded differently, with a lower richness in highly degraded habitats for the two most recent restored sites and no significant differences for the oldest one, which indicates a success of restoration on this metric over time. Species richness can hardly be used alone as restoration proxy in a maritime clifftop context, especially for spiders. This result has already been found by other authors (Matthews et al. 2009; Déri et al. 2011), but can hardly be generalized to all ecosystems. Some studies 
224 indeed proved the effectiveness of this metric for the same taxa, like Pétillon \& Garbutt (2008)

225 for spiders of disturbed salt marshes and Borchard et al. (2014) for plants of degraded mountain

226 heathlands. In a grassland context, spider and plant species richness can also be higher in

227 reference states (Perner \& Malt 2003; Borchard et al. 2014; DiCarlo \& DeBano 2018).

229 Species composition

230 Assemblage compositions of the two taxa (spiders and plants) were very different between the 231 three studied sites. Only a few plant and spider species were common to all sites. Differences 232 between plant assemblages are not surprising, maritime heathland being well differentiated 233 along Brittany's coast (Bioret 1989; Demartini 2016). Differences in spider assemblages 234 between sites is an interesting result that can be partly explained by their great sensitivity to 235 changes in environmental, including climatic, conditions (Pik et al. 2002; Andersen \& Majer 236 2004; Pearce \& Venier 2006) and by their high diversity (Roberts 1985).

237 Almost all assemblages from the different degradation states within a given site significantly 238 differed between each other. As expected, most of these differences were driven by changes in 239 turnover, nestedness being negligible in most cases. Such a pattern due to turnover is consistent 240 with other studies on spider and plant beta diversity (Schirmel \& Buchholz 2011; Rickert et al. 241 2012; Lafage et al. 2015; Coccia \& Fariña 2019; see also Almeida-neto et al. 2011).

242 The observed patterns validate our hypothesis of a higher heterogeneity in reference states as 243 compared to references states that also increases over time since restoration. Both spiders and 244 plants displayed this pattern, which is consistent with several previous studies that showed 245 similar responses of these taxa (Perner \& Malt 2003; Ilg et al. 2008; Rickert et al. 2012; Lafage 246 et al. 2015). 
247 Therefore heterogeneity, as revealed by analyses of beta-diversity, can be used as a restoration 248 criteria of coastal heathland restoration for both spider and plant assemblages. Spiders appear 249 to increase in heterogeneity over time, but without converging toward the same referential state.

250 Differences in sites could explain such a result. It has indeed been shown that spider beta 251 diversity is strongly impacted by landscape-level factors (Carvalho et al. 2011; Lafage et al. 252 2015). The three sampling sites are split between continental (S15) and islands (S5 \& S11), and 253 also show a temperature gradient from North to South, which are some example on how site specificity may induce differences in landscape composition. Spider assemblages in all three sites became more and more variable with an increasing restoration level but differently for each site, which is probably driven by site-specific ecological variables. Spider assemblages are known to be shaped by the interplay of environmental structures (Uetz 1991), and to rapidly colonize empty niches (Pearce \& Venier 2006; Cristofoli et al. 2010; Borchard et al. 2014). As

259 the environment tends to be more complex along the restoration process, spiders that are known 260 for their high dispersion abilities (e.g. Foelix 2011) colonize habitats from the surrounding 261 landscapes.

262 Contrary to spiders, plant beta diversity is known to be mostly driven by local factors (Lafage 263 et al. 2015). Coastal heathlands are constraining habitats (Bioret \& Géhu 2008), which can 264 induce a stable reference state for plants toward which degraded states are converging. The 265 remaining differences with assemblages of reference state could come from the restoration 266 dynamic that stabilized into an alternative stable state (Leroy 2019).

269 Ground-dwelling spiders were both abundant and diverse in pitfall traps (they were actually the 270 dominant predators here: Hacala et al. unpublished data), which confirms their value as 
271 potential bio-indicators. The low and inconsistent number of reference indicator species concurs

272 with the hypothesis of a heterogeneous reference habitat driven by site specificity. That was

273 especially true for the site S5, where no indicator species of the reference state was found. This

274 might be due to the fact that the dominant plant species of this habitat was Erica vagans that 275 creates more patchy vegetation, hereby inducing more spatial heterogeneity in spider 276 assemblages than in the two other sites and preventing the highlight of indicator species. Since 277 habitat structure is known to be a strong driver of spider assemblages (e.g. Uetz 1991), the 278 heterogeneity in reference state of site S5 may induce variations that prevent indicator species 279 to be detected. The number of indicator species in degraded states decreased with increasing 280 restoration from S5 to S15. This expected shift in assemblage composition with more specialist 281 species in preserved habitats is consistent with other previous studies (Bonte et al. 2006; 282 Cristofoli et al. 2010). The higher number of indicator species in MD than in HD state is 283 probably linked to the greater number of ecological niches in MD, whereas HD state is mostly 284 characterized by high levels of bare grounds. Several indicator species found in this study match 285 well with their known ecology. Degraded habitats were associated with open habitat species 286 like Linyphiidae (e.g. Erigone dentipalpis, Diplostyla concolor etc.) and reference states were 287 more characterized by plant-dwelling species (e.g. Pardosa nigriceps, Zora spinimana etc).

288 Finally, the absence of plant indicator species strongly invalidates our hypothesis about the ratio 289 of indicator species between spiders and plants. This result could be due to the relatively low 290 spatial scale of sites together with the high dispersal ability of plants (Dufrêne \& Legendre 291 1997).

Concluding remarks

294 Recovery is still on-going after 15 years after initiating restoration, with no recovery of 295 reference assemblages for both plants and spiders. There were some signals that in the oldest 
restoration site, HD resembles MD in terms of spider and plant species composition (although the latter was significant different between degradation states), and plant species richness. This study allows us to confirm what has been shown in other ecosystems (Babin-Fenske \& Anand 2010; Borchard et al. 2014; McCary et al. 2015; Cole et al. 2016), i.e. arthropods strongly responds to disturbance through changes in assemblage composition and species occurrence. Monitoring both these taxa should provide a better understanding of the restoration dynamic (Harry et al. 2019). The use of multiple bio-indicators, as the ones shown in this study, seems to be the best way of assessing restoration operation (Lambeck 1997; Sattler et al. 2013; Fournier et al. 2015; Harry et al. 2019). This was illustrated here by the complementary responses of spiders and plants. Our study is consistent with previous studies that showed arthropod assemblages respond differently to disturbances compared to vegetation (BabinFenske \& Anand 2010; Feest et al. 2011; Spake et al. 2016, Harry et al. 2019), because of their greater diversity (Longcore 2003) and sensitivity to changes in microhabitat (Pearce \& Venier 2006). Thus a habitat where vegetation has been restored does not mean that arthropods are restored as well (Pétillon et al. 2014), and the other way around may probably apply.

These results stress the need to use multiple taxa in restoration studies as one cannot necessarily be the proxy of others (Coelho et al. 2009; Gerlash et al. 2013). Taxa from various trophic guilds, such as detrivorous, phytophagous or polyphagous arthropods (e.g. weevils, ground beetles or ants respectively), will be studied in the future since they are also likely to display different and complementary information (Lafage et al. 2015; Coccia \& Fariña 2019). Such comparisons groups should be done using functional or phylogenetical (Pavoine \& Ricotta 2014; Cardoso et al. 2015) distances aside from taxonomic one to understand the dynamics of arthropod assemblages, and therefore the ongoing, complex, processes that drive them. 
321 We thank Denis Lafage and Kaïna Privet for fruitful discussions, Aurélien Ridel and Timothée

322 Scherer for their help in identifying spiders and sorting samples respectively, and "Bretagne

323 Vivante" and "Communauté de communes de Belle-île-en-Mer" for continuous support during

324 fieldwork. Two anonymous reviewers and Marie Handock provided constructive comments on 325 a first draft.

326 


\section{Bibliography}

328 Almeida-Neto M, Frensel DM, Ulrich W (2011) Rethinking the relationship between nestedness and beta diversity: a comment on Baselga (2010). Global Ecology and Biogeography 21(7): 772-777.

Allen EB (1998) Response. Restoration Ecology 6:134-134

Andersen AN, Majer JD (2004) Ants show the way down under: invertebrates as bioindicators in land management. Frontiers in Ecology and the Environment 2:291-298

Babin-Fenske J, Anand M (2010) Terrestrial insect communities and the restoration of an industrially perturbed landscape: assessing success and surrogacy. Restoration Ecology 18:73-84

Bargmann T, Hatteland BA, Grytnes JA (2015) Effects of prescribed burning on carabid beetle diversity in coastal anthropogenic heathlands. Biodiversity and Conservation 24(10):2565-2581

Baselga A (2010) Partitioning the turnover and nestedness components of beta diversity. Global Ecology and Biogeography 19:134-143

Baselga A (2012) The relationship between species replacement, dissimilarity derived from nestedness, and nestedness. Global Ecology and Biogeography 21:1223-1232

Baselga A, Orme D, Villeger S, De Bortoli J, Leprieur F (2018). betapart: Partitioning Beta Diversity into Turnover and Nestedness Components. R package version 1.5.1. https:/CRAN.R-project.org/package=betapart

Bell JR, Rod Cullen W, Wheater P (1998) The structure of spider communities in limestone quarry environments. In Proceedings of the 17th European Colloquium of Arachnology. British Arachnological Society, Burnham Beeches, Bucks. 253-259

Bioret F (1989) Contribution à l'étude de la flore et de la végétation de quelques îles et archipels ouest et sud armoricains. Ph.D. thesis, Université de Nantes, Nantes, France

Bioret F, Géhu J-M (2008) Révision phytosociologique des végétations halophiles des falaises littorales atlantiques françaises. Fitosociologia 45:75-116

Bonte D, Lens L, Maelfait JP (2006) Sand dynamics in coastal dune landscapes constrain diversity and life-history characteristics of spiders. Journal of Applied Ecology 43:735-747 
Borchard F, Buchholz S, Helbing F, Fartmann T (2014) Carabid beetles and spiders as bioindicators for the evaluation of montane heathland restoration on former spruce forests. Biological Conservation 178:185192

Bourlet Y (1980) Les landes de Bretagne septentrionale. Etudes de biogéographie végétale. Norois 107:417-432

Cardoso P, Rigal F, Carvalho J C (2015). BAT - Biodiversity Assessment Tools, an R package for the measurement and estimation of alpha and beta taxon, phylogenetic and functional diversity. Methods in Ecology and Evolution 6(2): 232-236. doi:10.1111/2041-210x.12310

Caro TM, O’Doherty G (1999) On the use of surrogate species in conservation biology. Conservation Biology $13: 805-814$

Carvalho JC, Cardoso P, Crespo LC, Henriques S, Carvalho R, Gomes P (2011) Determinants of beta diversity of spiders in coastal dunes along a gradient of mediterraneity. Diversity and Distributions 17(2):225-234

Chao A (1984) Nonparametric estimation of the number of classes in a population. Scandinavian Journal of Statistics 11:265-270

Chao A (1987) Estimating the population size for capture-recapture data with unequal catchability. Biometrics 43:783-791

Chao A, Gotelli NJ, Hsieh TC, Sander EL, Ma KH, Colwell RK, Ellison AM (2014) Rarefaction and extrapolation with Hill numbers: a framework for sampling and estimation in species diversity studies. Ecological Monographs 84: 45-67

Coccia C, Fariña JM (2019) Partitioning the effects of regional, spatial, and local variables on beta diversity of salt marsh arthropods in Chile. Ecology and Evolution 9(5): 2575-2587

Coelho MS, Quintino AV, Fernandes GW, Santos JC, Delabie JHC (2009) Ants (hymenoptera: formicidae) as bioindicators of land restoration in a Brazilian Atlantic forest fragment. Sociobiology 54(1):51-63

377 Cole RJ, Holl KD, Zahawi RA, Wickey P, Townsend AR (2016) Leaf litter arthropod responses to tropical forest restoration. Ecology and Evolution 6:5158-5168

379 Cristofoli S, Mahy G, Kekenbosch R, Lambeets K (2010) Spider communities as evaluation tools for wet heathland restoration. Ecological Indicators 10:773-780

381 Demartini C (2016) Les végétations des côtes Manche-Atlantique françaises: essai de typologie et de cartographie dynamico-caténales. Ph.D. thesis, Université de Bretagne occidentale - Brest 
Déri E, Magura T, Horváth R, Kisfali M, Ruff G, Lengyel S, Tóthmérész B (2011) Measuring the short-term success of grassland restoration: The use of habitat affinity indices in ecological restoration. Restoration Ecology 19:520-528

Desdoigts J-Y (2000) L'extrémité du Cap Sizun : restauration de la nature et tourisme. L'opération grand site de la pointe du Raz, de la pointe du Van et de la baie des Trépassés. Norois 186:283-293

DiCarlo LAS, DeBano SJ (2018) Spider community responses to grassland restoration: balancing trade-offs between abundance and diversity. Restoration Ecology 27(1): 210-219

Dufrêne M, Legendre P (1997) Species assemblages and indicator species: the need for a flexible asymmetrical approach. Ecological Monographs 67:345-366

Feest A, Merrill I, Aukett P (2011) Does botanical diversity in sewage treatment reed-bed sites enhance invertebrate biodiversity? International Journal of Ecology 1:1-9

Foelix R (2011) Biology of spiders. OUP USA.

Fournier B, Gillet F, Le Bayon RC, Mitchell EA, Moretti M (2015) Functional responses of multitaxa communities to disturbance and stress gradients in a restored floodplain. Journal of Applied Ecology 52:1364-1373

Gatica-Saavedra P, Echeverría C, Nelson CR (2017) Ecological indicators for assessing ecological success of forest restoration: a world review. Restoration Ecology 25:850-857

Gerlach J, Samways M, Pryke J (2013) Terrestrial invertebrates as bioindicators: an overview of available taxonomic groups. Journal of Insect Conservation 17:831-850

Harry I, Höfer H, Schielzeth H, Assman T (2019) Protected habitats of Natura 2000 do not coincide with important diversity hotspots of arthropods in mountain grasslands. Insect Conservation and Diversity 12(4):329338

Ilg C, Dziock F, Foeckler F, Follner K, Gerisch M, Glaeser J, Rink A, Schanowski A, Scholz M, Deichner O, Henle K (2008) Long-term reactions of plants and macroinvertebrates to extreme floods in floodplain grasslands. Ecology 98(9):2392-2398

Klejin D, Baquero RA, Clough Y, Días M, De Esteban J, Fernández F, Gabriel D, Herzog F, Holzschuh A, Jöhl R, Knop E, Kruess A, Marshall EJP, Steffan-Dewenter I, Tscharntke T, Verhulst J, West TM, Yela JL (2006) Mixed biodiversity benefits of agri-environment schemes in five European countries. Ecology Lettres 9:243-254 
Kollmann J, Meyer ST, Bateman R, Conradi T, Gossner MM, de Souza Mendoza Jr. M, Fernandes GW, Hermann J-M, Koch C, Müller SC, Oki Y, Overbeck GE, Paterno GB, Rosenfield MF, Toma TSP, Weisser WW (2016) Integrating ecosystem functions into restoration ecology—recent advances and future directions. Restoration Ecology 24:722-730

Lafage D, Maugenest S, Bouzillé JB, Pétillon J (2015) Disentangling the influence of local and landscape factors on alpha and beta diversities: opposite response of plants and ground-dwelling arthropods in wet meadows. Ecological Research 30(6):1025-1035

Lafage D, Djoudi EA, Perrin G, Gallet S, Pétillon J (2019) Responses of ground-dwelling spider assemblages to changes in vegetation from wet oligotrophic habitats of Western France. Arthropod-Plant Interactions, in press. https://doi.org/10.1007/s11829-019-09685-0

Lambeck RJ (1997) Focal Species: A multi-species umbrella for nature conservation. Conservation Biology 11:849-856

Lang A (2000) The pitfalls of pitfalls: a comparison of pitfalls trap catches and absolute density estimates of epigeal invertebrate predators in arable land. Journal of Pest Science 73(4): 99-106

Leibold MA, Holyoak M, Mouquet N, Amarasekare P, Chase JM, Hoopes MF, Holt RD, Shurin JB, Law R, Tilman D, Loreau M, Gonzales A (2004) The metacommunity concept: a framework for multi-scale community ecology. Ecology Letters 7:601-613

Le Fur Y (2013) La patrimonialisation des grands sites : évolution des doctrines et transformation des espaces : exemple des promontoires littoraux emblématiques bretons. Ph.D. thesis, Université de Bretagne Occidentale, Brest, France

Le Roy M, Sawtschuk J, Bioret F, Gallet S (2019) Toward a social-ecological approach to ecological restoration: A look back at three decades of maritime clifftop restoration. Restoration Ecology 27(1): 228-238

Le Roy M (2019) Contribution à la connaissance socio-écologique des opérations de restoration des hauts de falaises littorales de Bretagne. Ph.D. thesis, Université de Bretagne Occidentale, Brest, France

Leroy B, Le Viol I, Pétillon J (2014) Complementarity of rarity, specialisation and functional diversity metrics to assess community responses to environmental changes, using an example of spider communities in salt marshes. Ecological Indicators 46: 351-357.

Longcore T (2003) Terrestrial arthropods as indicators of ecological restoration success in coastal sage scrub (California, U.S.A.). Restoration Ecology 11:397-409 
Malloch AJC (1972) Salt-spray deposition on the maritime cliffs of the lizard peninsula. Journal of Ecology 60:103-112

Matthews JW, Spyreas G, Endress AG (2009) Trajectories of vegetation-based indicators used to assess wetland restoration progress. Ecological Applications 19:2093-2107

McCary MA, Martinez J-C, Umek L, Heneghan L, Wise DH (2015) Effects of woodland restoration and management on the community of surface-active arthropods in the metropolitan Chicago region. Biological Conservation 190:154-166

Morrison ML (1998) Letter to the editor. Restoration Ecology 6:133-133

Nentwig W, Blick T, Gloor D, Hänggi A, Kropf C (2019) Version 06.2019. Online at https://www.araneae.nmbe.ch, accessed on 19/06/2019. doi: 10.24436/1

Oksanen J, Blanchet F G, Friendly M, Kindt R, Legendre P, McGlinn D, Minchin P R, O'Hara R B, Simpson G L, Solymos P, Stevens H M H, Szoecs E, Wagner H (2019). vegan: Community ecology package. R package version 2.5-4. https://CRAN.R-project.org/package=vegan

Minchin P R, O'Hara R B, Simpson G L, Solymos P, Henry M, Stevens H, Szoecs E, Wagner H (2019). vegan: Community ecology package. R package version 2.5-4. https://CRAN.R-project.org/package=vegan

Ossamy S, Elbanna SM, Orabi GM, Semida FM (2016) Assessing the potential role of spiders as bioindicators in Ashtoum el Gamil natural protected area, Port Said, Egypt. Indian J. Arachnol 5:101

Pavoine S, Ricotta C (2014) Functional and phylogenetic similarity among communities. Methods in Ecology and Evolution 5(7):666-675

Pearce JL, Venier LA (2006) The use of ground beetles (Coleoptera: Carabidae) and spiders (Araneae) as bioindicators of sustainable forest management: A review. Ecological Indicators 6:780-793

Perner J, Malt S (2003) Assessment of changing agricultural land use: response of vegetation, ground-dwelling spiders and beetles to the conversion of arable land into grassland. Agriculture, Ecosystems \& Environment 98:169-181

Pétillon J, Lasne E, Lambeets K, Canard A, Vernon P, Ysnel F (2010) How do alterations in habitat structure by an invasive grass affect salt-marsh resident spiders? Annales Zoologici Fennici 47:79-89

Pétillon J, Garbutt A (2008) Success of managed realignment for the restoration of salt-marsh biodiversity: preliminary results on ground-active spiders. Journal of Arachnology 36:388-393 
Pétillon J, Potier S, Carpentier A, Garbutt A (2014) Evaluating the success of managed realignment for the restoration of salt marshes: Lessons from invertebrate communities. Ecological Engineering 69:70-75

Pik AJ, Dangerfield JM, Bramble RA, Angus C, Nipperess DA (2002) The use of invertebrates to detect smallscale habitat heterogeneity and its application to restoration practices. Environmental Monitoring and Assessment 75:179-199

Rickert C, Fichtner A, Van Klink R, Bakker JP (2012) $\alpha$ - and $\beta$ - diversity in moth communities in salt marshes is driven by grazing management. Biological Conservation 146:24-31

Roberts MJ (1985) The spiders of Great Britain and Ireland. Brill Archive

Roberts D W (2016). labdsv: Ordination and multivariate analysis for ecology. R package version 1.8-0. https://CRAN.R-project.org/package=labdsv

Ruiz-Jaen MC, Aide TM (2005) Restoration success: how is it being measured? Restoration Ecology 13:569-577

Sattler T, Pezzatti GB, Nobis MP, Obrist MK, Roth T, Moretti M (2013) Selection of multiple umbrella species for functional and taxonomic diversity to represent urban biodiversity. Conservation Biology 00:1-13

Sawtschuk J (2010) Restauration écologique des pelouses et des landes des falaises littorales atlantiques : analyse des trajectoires successionnelles en environnement contraint. Ph.D. thesis, Université de Bretagne Occidentale, Brest, France

Sawtschuk J, Bioret F, Gallet S (2010) Spontaneous succession as a restoration tool for maritime cliff-top vegetation in Brittany, France. Restoration Ecology 18:273-283

Schirmel J, Blindow I, Buchholz S (2012) Life-history trait and functional diversity patterns of ground beetles and spiders along a coastal heathland successional gradient. Basic and Applied Ecology 13:606-614

Schirmel J, Buchholz S (2011) Response of carabid beetles (Coleoptera: Carabidae) and spiders (Araneae) to coastal heathland succession. Biodiversity and Conservation 20(7):1469

Spake R, Barsoum N, Newton AC, Doncaster CP (2016) Drivers of the composition and diversity of carabid functional traits in UK coniferous plantations. Forest Ecology and Management 359:300-308

Topping CJ, Sunderland KD (1992) Limitations to the use of pitfall traps in ecological studies exemplified by a study of spiders in a field of winter wheat. Journal of Applied Ecology 485-491.

Uetz GW (1991) Habitat structure and spider foraging. In Habitat structure. Springer, Dordrecht, pp 325-348

Varet M, Burel F, Lafage D, Pétillon J (2013) Age-dependent colonization of urban habitats : a diachronic approach using carabid beetles and spiders. Animal Biology 63:257-269 
497 Wickham H (2016) ggplot2: Elegant graphics for data analysis. Springer-Verlag New York.

498 Wortley L, Hero J-M, Howes M (2013) Evaluating ecological restoration success: A review of the literature. 499 Restoration Ecology 21:537-543

500 Young TP (2000) Restoration ecology and conservation biology. Biological Conservation 92:73-83

501 
503

504 Table 1. Comparison of partitioned beta-diversities computed using Sørensen dissimilarity 505 matrices between degradation states (RF: Reference; MD: Midly degraded; HD: Highly 506 degraded).

507

\begin{tabular}{ccccc}
\hline Spiders & & S5 & S11 & S15 \\
& & & & \\
RF & Turnover & 0.73 & 0.67 & 0.73 \\
& Nestedness & 0.03 & 0.05 & 0.07 \\
& & & & \\
MD & Turnover & 0.56 & 0.63 & 0.68 \\
& Nestedness & 0.04 & 0.06 & 0.06 \\
& & & & \\
HD & Turnover & 0.55 & 0.67 & 0.67 \\
& Nestedness & 0.15 & 0.06 & 0.09
\end{tabular}

\begin{tabular}{|c|c|c|c|c|}
\hline Plants & & S5 & S11 & S15 \\
\hline \multirow{2}{*}{ RF } & Turnover & 0.65 & 0.48 & 0.59 \\
\hline & Nestedness & 0.04 & 0.17 & 0.07 \\
\hline \multirow{2}{*}{$\mathrm{MD}$} & Turnover & 0.66 & 0.47 & 0.56 \\
\hline & Nestedness & 0.05 & 0.08 & 0.04 \\
\hline \multirow{2}{*}{ HD } & Turnover & 0.49 & 0.40 & 0.52 \\
\hline & Nestedness & 0.08 & 0.10 & 0.11 \\
\hline
\end{tabular}


510 Table 2. Number of significant indicator species (IndVal $>0.5$, for species names of spiders see

511 appendix 4) of each degradation state (RF: Reference; MD: Moderately degraded; HD: Highly 512 degraded).

513

\begin{tabular}{|c|c|c|c|}
\hline & S5 & S11 & S15 \\
\hline \multicolumn{4}{|l|}{ Spiders } \\
\hline $\mathrm{RF}$ & 0 & 9 & 1 \\
\hline MD & 14 & 2 & 0 \\
\hline HD & 4 & 1 & 0 \\
\hline \multicolumn{4}{|l|}{ Plants } \\
\hline $\mathrm{RF}$ & 0 & 0 & 0 \\
\hline MD & 0 & 0 & 0 \\
\hline HD & 0 & 0 & 0 \\
\hline
\end{tabular}

514

515 
516 Figure 1. Theoretical expectations regarding changes in assemblage heterogeneity (circle

517 diameter) and Indicator (green) vs generalist (bleu) species over time to restauration and along 518 a degradation intensity gradient. Figure made with GIMP 2.

519
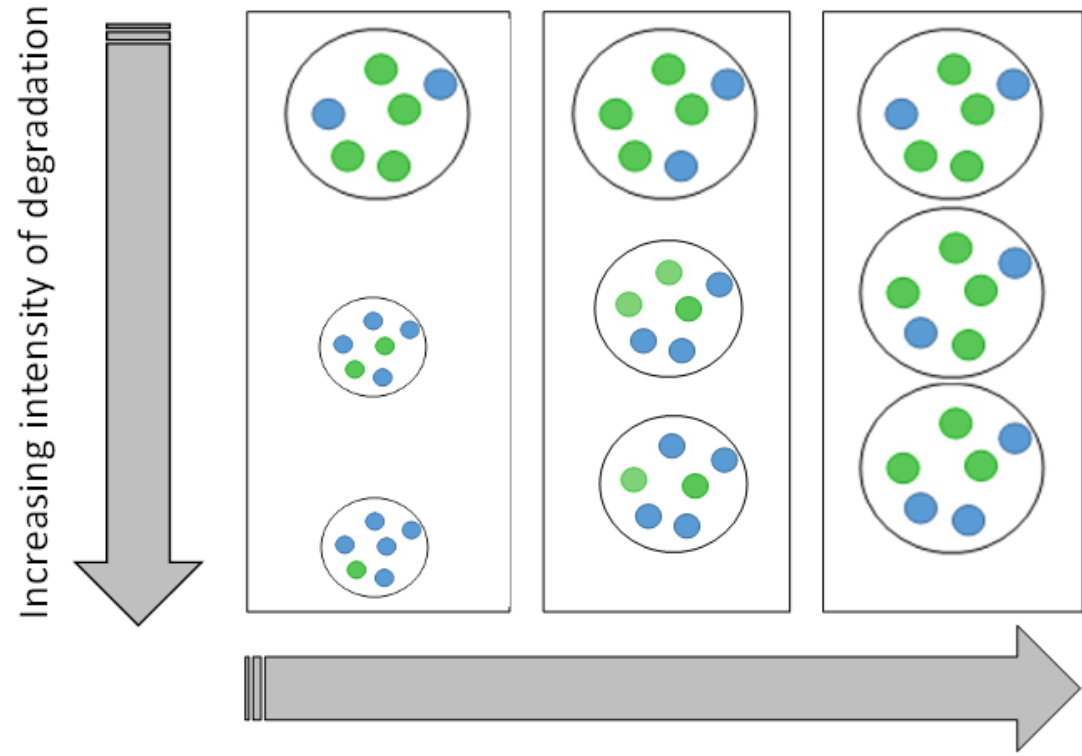

Increasing time from restoration 
521 Figure 2. Estimated species richness for spiders and plants in each degradation state of the three

522 sites (Highly degraded: red curve; Mildly degraded: blue curve; Reference: green curve). The

523 coloured area around the curves represents the 95\% confidence interval based on the bootstrap

524 method. Figure made with R and iNext package (Chao et al. 2014)

525

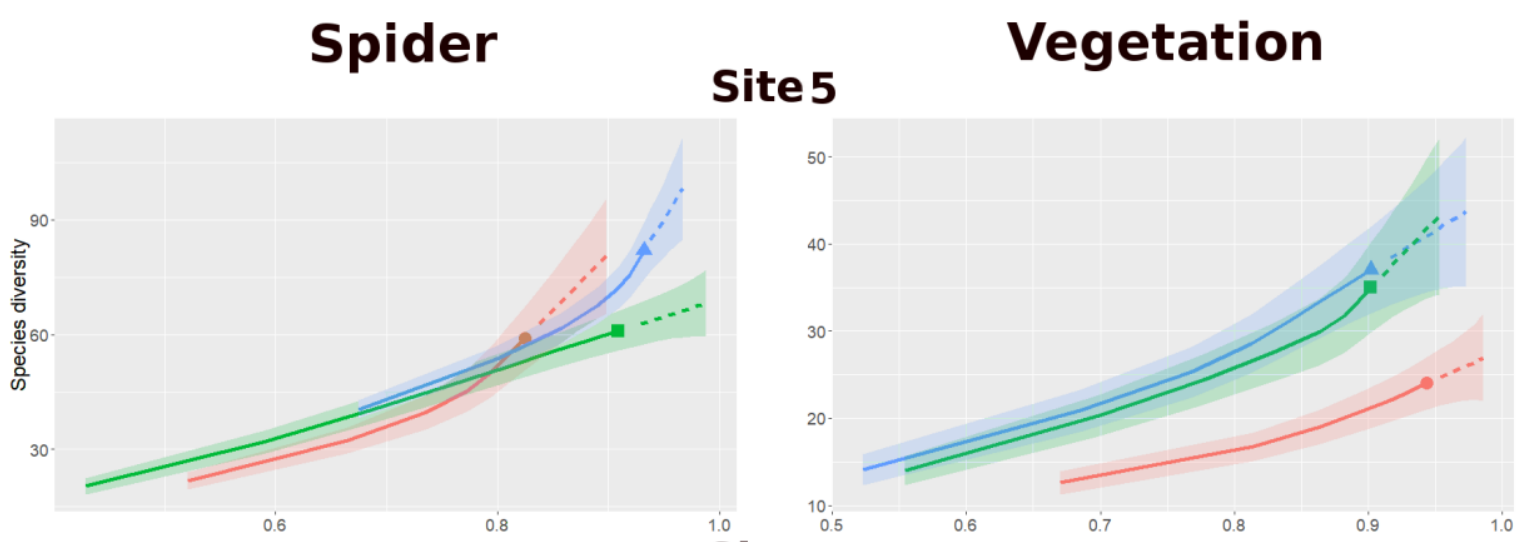

Site 11

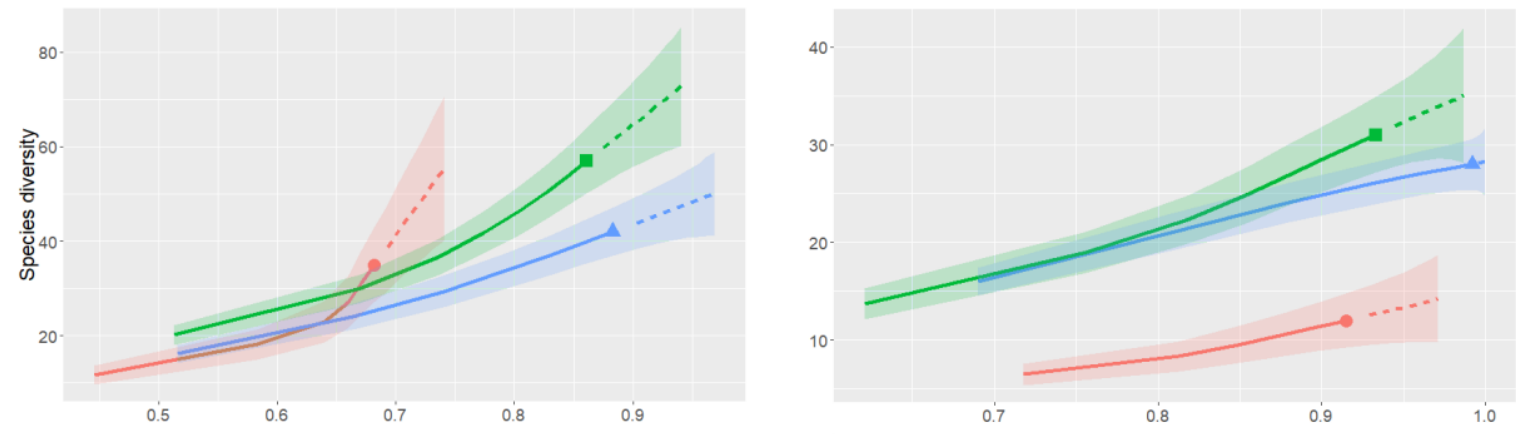

Site 15
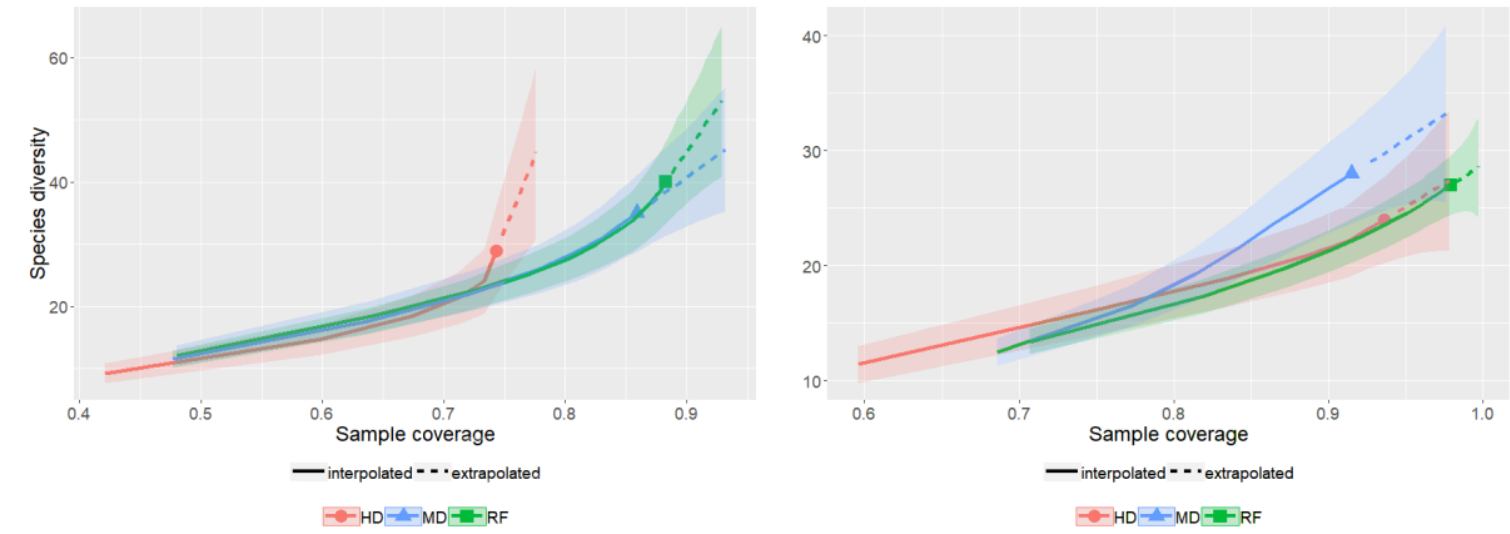
527 Figure 3. NMDS based on Sørensen dissimilarity matrix for spider and plant assemblages with

528 the envelopes grouping sites. Venn diagrams with the number of species unique or shared by 529 site for each taxa. Figure made with R with ggplot2 package (Wickham 2016).
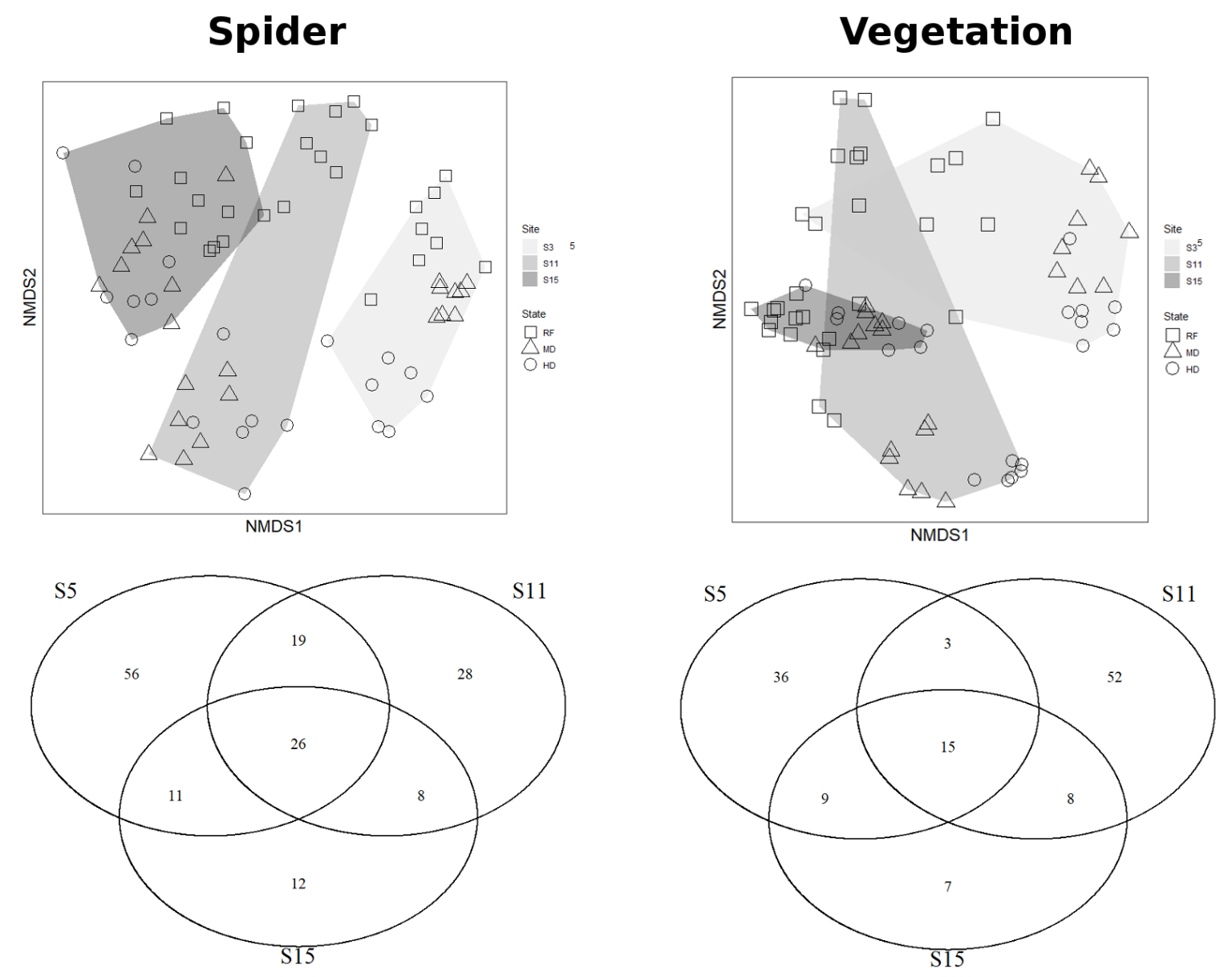
531 Appendix 1. Localisation and characteristics of the three study sites (Brittany, Western France).

$532 \quad$ Figure made with GIMP 2.

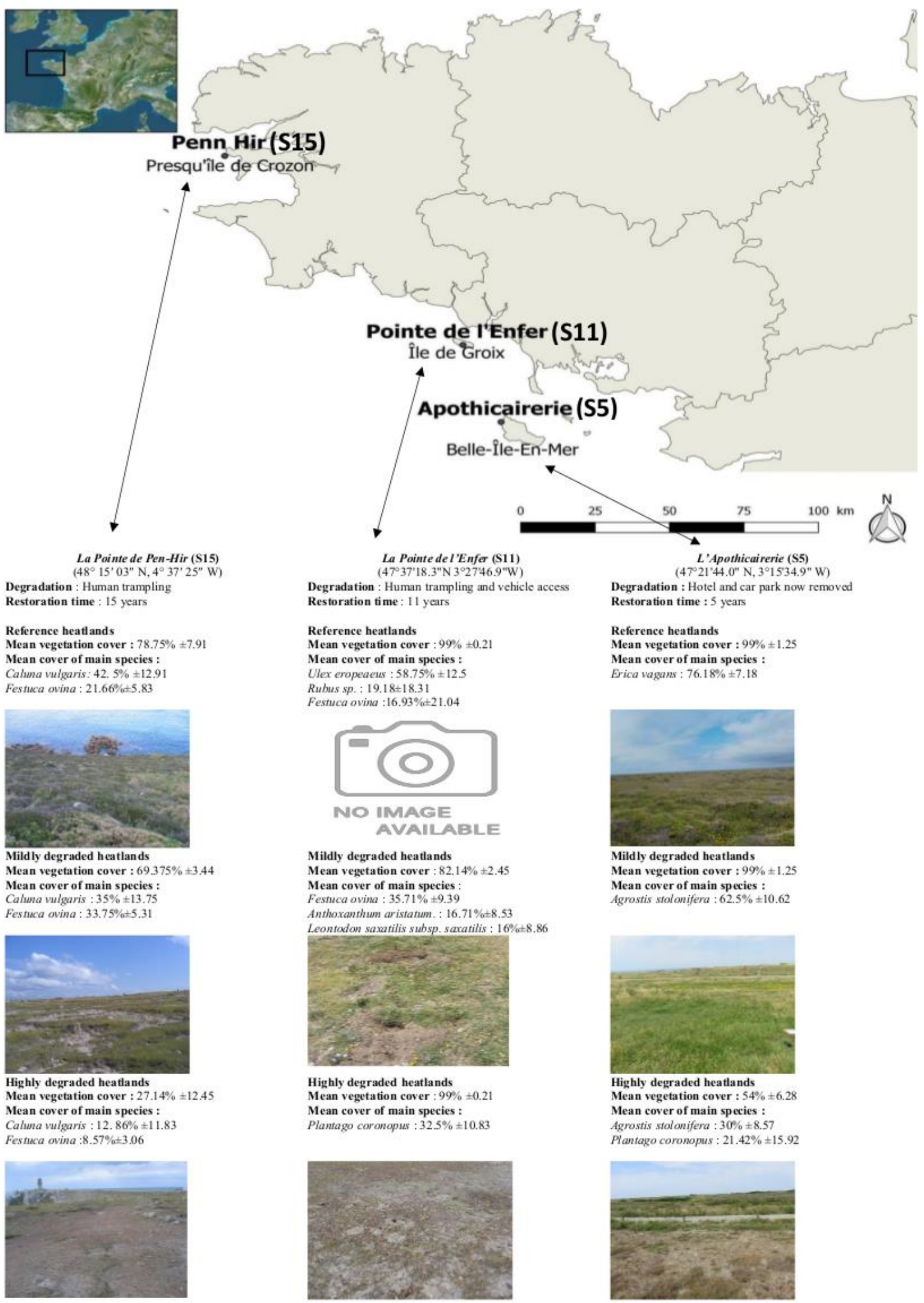


534 Appendix 2. Accumulation curves for a) spider and b) plant sampling coverage. Curve colours

535 correspond to different sampling sites (Blue: S5; Red: S11; Green: S15). The coloured area 536 around the curves is the 95\% confidence interval based on bootstrapping (see Methods for more

537 details). Figure made with $\mathrm{R}$ and iNext package (Chao et al. 2014).

538

539

540
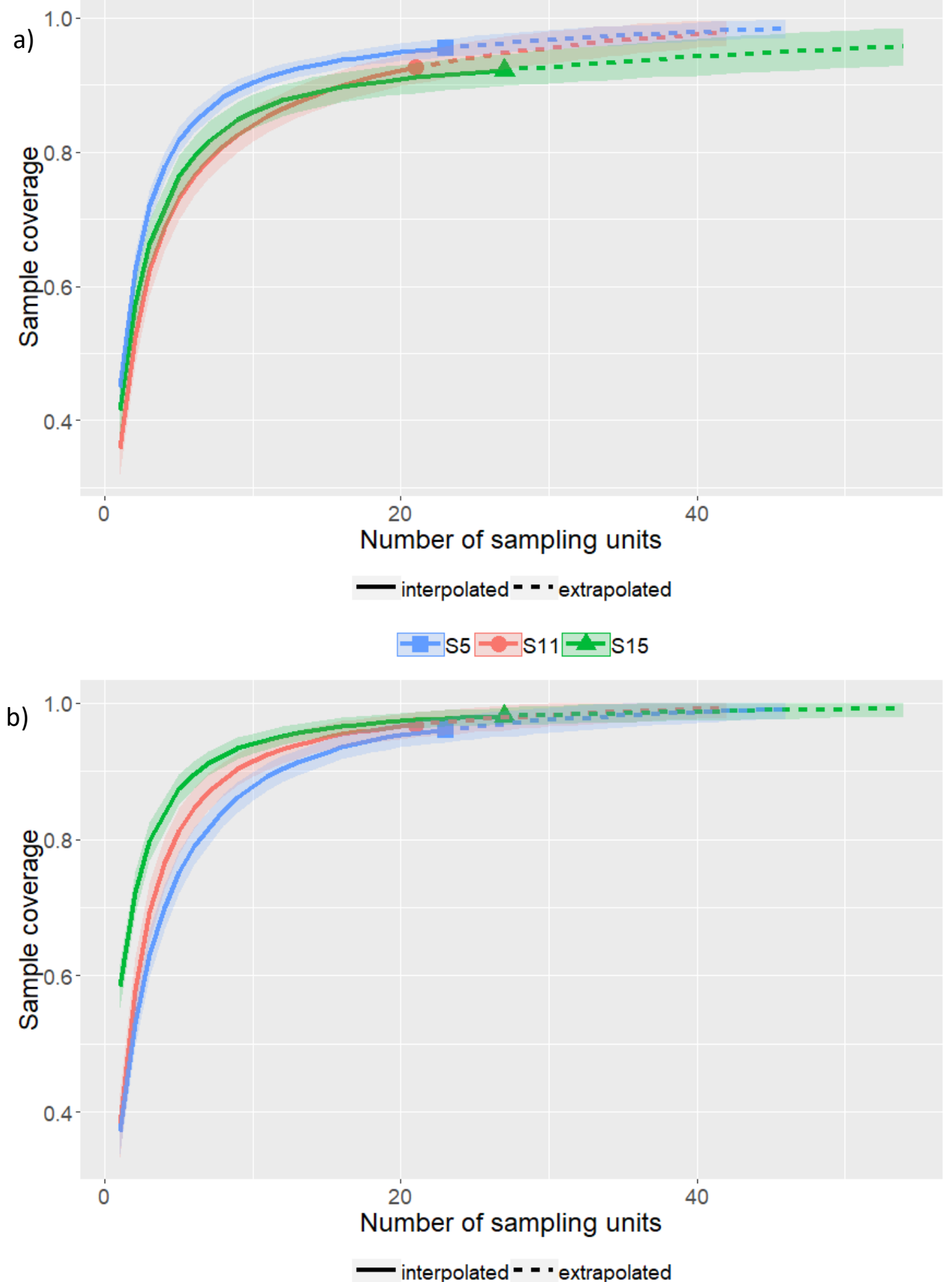
541 Appendix 3. Spider species presence/absence by site. Index letters indicate significant indicator 542 species of $\mathrm{a}=$ Reference, $\mathrm{b}=$ Mildly degraded and $\mathrm{c}=$ Highly degraded states.

\section{species}

Alopecosa barbipes

Acartauchenius scurrilis

Agrocea cuprea

Agroeca brunnea

Agroeca inopina

Agroeca lusatica

Agyneta rurestris

Alopecosa farinosa

Alopecosa cuneata

Alopecosa pulverulenta

Amaurobius erberi

Anelosimus pulchellus

Antistea elegans

Arctosa cf. vilica

Arctosa leopardus

Arctosa perita

Argenna patula

Argenna subnigra

Asagena phalerata

Atypus affinis

Aulonia albimana

Ballus rufipes

Bathyphantes gracilis

Centromerita bicolor

Centromerita concina

Centromerus prudens

Cheiracanthium erraticum

Civizelotes civicus

Clubiona comta

Clubiona genevensis

Clubiona phragmitis

Clubiona reclusa

Clubiona terrestris

Crustulina guttata

Crustulina sticta

Dictyna arundinacea

Diplostyla concolor

Dipoena erythropus

Dipoena prona

Drassodes cf. lapidosus

Drassodes pubescens

Drassylus praeficus

\section{S5 S11}

S15

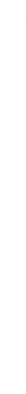

$\begin{array}{ccc}0^{\mathrm{b}} & 0 & 1 \\ 0 & 1 & 0 \\ 1 & 0 & 0 \\ 1 & 0 & 0 \\ 1 & 1^{\mathrm{a}} & 1\end{array}$

$\begin{array}{lll}0 & 1 & 0\end{array}$

$\begin{array}{lll}1^{\mathrm{c}} & 1 & 1\end{array}$

$\begin{array}{lll}1 & 0 & 1\end{array}$

$\begin{array}{lll}1 & 0 & 0\end{array}$

$\begin{array}{lll}1^{\mathrm{b}} & 1 & 1\end{array}$

$\begin{array}{lll}0 & 1^{\mathrm{a}} & 1\end{array}$

$\begin{array}{lll}1^{\text {c }} & 0 & 0\end{array}$

$\begin{array}{lll}1 & 0 & 0\end{array}$

$\begin{array}{lll}0 & 1 & 0\end{array}$

$\begin{array}{lll}1 & 0 & 0\end{array}$

$\begin{array}{lll}1 & 0 & 0\end{array}$

$\begin{array}{lll}0 & 1 & 0\end{array}$

$\begin{array}{lll}1 & 1 & 1\end{array}$

$\begin{array}{lll}0 & 0 & 1\end{array}$

$\begin{array}{lll}0 & 1 & 0\end{array}$

$\begin{array}{lll}1 & 1 & 1\end{array}$

$\begin{array}{lll}1 & 0 & 0\end{array}$

$\begin{array}{lll}0 & 1 & 0\end{array}$

$\begin{array}{lll}1 & 0 & 0\end{array}$

$\begin{array}{lll}0 & 0 & 1\end{array}$

$\begin{array}{lll}1 & 0 & 0\end{array}$

$\begin{array}{lll}1 & 0^{\mathrm{b}} & 0\end{array}$

$\begin{array}{lll}0 & 1 & 0\end{array}$

$\begin{array}{lll}0 & 1 & 0\end{array}$

$\begin{array}{lll}0 & 1 & 0\end{array}$

$\begin{array}{lll}1 & 0 & 0\end{array}$

$\begin{array}{lll}0 & 0 & 1\end{array}$

$\begin{array}{lll}0 & 0 & 1\end{array}$

$\begin{array}{lll}1 & 1 & 1\end{array}$

$\begin{array}{lll}1 & 1 & 0\end{array}$

$\begin{array}{lll}0 & 1 & 0\end{array}$

$\begin{array}{lll}1^{\mathrm{b}} & 0 & 0\end{array}$

$\begin{array}{lll}1 & 0 & 0\end{array}$

$\begin{array}{lll}1 & 0 & 1\end{array}$

$\begin{array}{lll}1 & 1 & 1\end{array}$

$\begin{array}{lll}1 & 1 & 1 \\ 1 & 0 & 0\end{array}$

$\begin{array}{lll}1 & 0 & 0\end{array}$

species

S5 S11

Micromata ligurina

Micrommata virescens

Neon reticulatus

Neottiura suaveolens

Neriene clathrata

Nomisia exornata

Oedothorax fuscus

Oedothorax retusus

Ostearius melanopygius

Ozyptila atomaria

Ozyptila sanctuaria

Ozyptila scabricula

Ozyptila simplex

Palliduphantes ericaeus

Palliduphantes insignis

Palliduphantes pallidus

Pardosa pullata

Pardosa amentata

Pardosa monticola

Pardosa nigriceps

Pardosa palustris

Pardosa prativaga

Pardosa proxima

Pardosa pullata

Pardosa saltans

Peponocranium ludicrum

Phaeocedus braccatus

Philodromus cf. rufus

Philodromus aureolus

Phlegra bresnieri

Phlegra fasciata

Pholcomma gibbum

Phrurolithus festivus

Phrurolithus minimus

Phrurolithus nigrinus

Pocadicnemis pumila

Poecilochroa variana

Robertus arundineti

Robertus lividus

Saaristoa abnormis

Segestria senoculata

Silometopus elegans

\begin{tabular}{|c|c|}
\hline 0 & 1 \\
\hline 0 & 0 \\
\hline 1 & 0 \\
\hline 0 & 1 \\
\hline 0 & $1^{b}$ \\
\hline 1 & 1 \\
\hline 0 & 1 \\
\hline 0 & 1 \\
\hline 0 & 1 \\
\hline $1^{\mathrm{b}}$ & 0 \\
\hline 0 & 1 \\
\hline $1^{\mathrm{b}}$ & 0 \\
\hline $1^{\mathrm{b}}$ & 1 \\
\hline 1 & 1 \\
\hline $1^{\mathrm{b}}$ & 0 \\
\hline 1 & 0 \\
\hline 0 & 1 \\
\hline 1 & 1 \\
\hline 1 & $1^{\mathrm{a}}$ \\
\hline 1 & 0 \\
\hline $1^{\mathrm{b}}$ & 0 \\
\hline 1 & 0 \\
\hline $1^{\mathrm{b}}$ & 1 \\
\hline 0 & 1 \\
\hline 1 & 0 \\
\hline 1 & 0 \\
\hline 0 & 1 \\
\hline 1 & 0 \\
\hline 0 & 1 \\
\hline 0 & 1 \\
\hline 1 & 0 \\
\hline 1 & 0 \\
\hline 0 & 1 \\
\hline 1 & 0 \\
\hline $1^{\mathrm{b}}$ & 0 \\
\hline 1 & 1 \\
\hline 1 & 0 \\
\hline 1 & 1 \\
\hline 1 & 1 \\
\hline 0 & 0 \\
\hline 1 & 0 \\
\hline
\end{tabular}




\begin{tabular}{|c|c|c|}
\hline Drassylus pusillus & 1 & 0 \\
\hline Drassylus villicus & 1 & 0 \\
\hline Dysdera crocata & 1 & 0 \\
\hline Dysdera erythrina & 1 & $1^{\mathrm{a}}$ \\
\hline Dysdera fuscipes & 0 & 1 \\
\hline Enoplognatha thoracica & 1 & 1 \\
\hline Enterlecara erythropus & 1 & 0 \\
\hline Episinus truncatus & 0 & 1 \\
\hline Eratigena picta & 1 & 1 \\
\hline Erigone atra & 0 & 1 \\
\hline Erigone dentipalpis & $1^{\mathrm{c}}$ & $1^{\mathrm{c}}$ \\
\hline Ero furcata & 1 & 1 \\
\hline Euophris semiglabrata & 1 & 0 \\
\hline Euophrys frontalis & 0 & 1 \\
\hline Euophrys herbigrada & 1 & 1 \\
\hline Gnaphosa lugubris & 1 & 1 \\
\hline Gnaphosa occidentalis & 1 & 1 \\
\hline Gonatium rubens & 0 & 1 \\
\hline Hahnia nava & $1^{\mathrm{b}}$ & 1 \\
\hline Haplodrassus dalmatensis & $1^{\mathrm{c}}$ & 1 \\
\hline Haplodrassus signifer & 1 & 1 \\
\hline Haplodrassus umbratilis & 1 & 0 \\
\hline Harpactea hombergi & 1 & 1 \\
\hline Heliophanus auratus & 1 & 0 \\
\hline Heliophanus cupreus & 0 & 1 \\
\hline Hypsosinga albovittata & 1 & 1 \\
\hline Lasaeola coracina & 1 & 0 \\
\hline Lasaeola prona & 0 & 0 \\
\hline Lathys humilis & 0 & 0 \\
\hline Mangora acalypha & 0 & 1 \\
\hline Marpissa nivoyi & 0 & 1 \\
\hline Mecopisthes peusi & 0 & 1 \\
\hline Megalepthyphantes nebulosus & 1 & 0 \\
\hline Meioneta innotabilis & 1 & 0 \\
\hline Mermessus trilobatus & $1^{\mathrm{b}}$ & 1 \\
\hline Metopobractus prominulus & 1 & 0 \\
\hline Micaria albovittata & 1 & 0 \\
\hline Micaria formicaria & 1 & 0 \\
\hline Micaria pulicaria & 1 & 0 \\
\hline Microlinyphia pusilla & 0 & 1 \\
\hline
\end{tabular}

Steatoda phalerata

Stemonyphantes lineatus

Styloctetor compar

Talavera aequipes

Tenuiphantes flavipes

Tenuiphantes tenuis

Thanatus striatus

Tiso vagans

Trachyzelotes pedestris

Trichoncus saxicola

Trochosa robusta

Trochosa ruricola

Trochosa terricola

Walckenaeria acuminata

Walckenaeria alticeps

Walckenaeria capito

Walckenaeria dysderoides

walckenaeria clavicornis

Walckenaeria furcillata

Walckenaeria monoceros

Walckenaeria nudipalpis

Xysticus cristatus

Xysticus erraticus

Xysticus kempeleni

Xysticus kochi

Xysticus lanio

Zelotes atrocaeruleus

Zelotes latreillei

Zelotes pedestris

Zelotes petrensis

Zelotes praeficus

Zelotes pusillus

Zelotes subterraneus

Zodarion italicum

Zora armillata

Zora spinimana

\begin{tabular}{|c|c|}
\hline 1 & 0 \\
\hline 1 & 1 \\
\hline 1 & 0 \\
\hline 1 & 0 \\
\hline 1 & 1 \\
\hline 1 & 1 \\
\hline 1 & 0 \\
\hline 1 & $1^{\mathrm{a}}$ \\
\hline 1 & 1 \\
\hline $1^{\mathrm{b}}$ & 0 \\
\hline 0 & 1 \\
\hline 0 & 1 \\
\hline $1^{\mathrm{b}}$ & 1 \\
\hline 0 & 0 \\
\hline 1 & 0 \\
\hline 0 & 1 \\
\hline 0 & 0 \\
\hline 1 & 0 \\
\hline 1 & 1 \\
\hline 1 & 0 \\
\hline 1 & 1 \\
\hline 1 & 0 \\
\hline 1 & 0 \\
\hline 1 & $1^{\mathrm{a}}$ \\
\hline 1 & 1 \\
\hline 0 & 0 \\
\hline 1 & $1^{\mathrm{a}}$ \\
\hline 1 & 0 \\
\hline 0 & $1^{\mathrm{a}}$ \\
\hline 1 & 0 \\
\hline 0 & 1 \\
\hline 1 & 0 \\
\hline 1 & 0 \\
\hline 1 & 1 \\
\hline 1 & 0 \\
\hline 1 & $1^{\mathrm{a}}$ \\
\hline
\end{tabular}


544 Appendix 4. Plant species presence/absence by site.

species

Agrostis capillaris

Agrostis stolonifera

Aira caryophyllea

Aira praecox

Anagallis arvensis

Anthoxanthum aristatum

Anthoxanthum odoratum

Anthyllis vulneraria

Armeria maritima

Arrhenatherum elatius

Asparagus officinalis ssp. prostratus

Atriplex hastata

Atriplex sp.

Avena fatua

Brachypodium sp.

Bromus hordeaceus ssp. ferronii

Calluna vulgaris

Carex distans

Carex sp.

Centaurea nigra

Centaurea sp.

Centaurium erythraea

Centaurium maritimum

Centaurium sp.

Cerastium diffusum

Cerastium fontanum

Chamaemelum nobile

Cirsium arvense

Cirsium filipendulum

Cirsium vulgare

Cochlearia danica

Convolvulus arvensis

Crepis sp.

Crepis capillaris

Crithmum maritimum

Cuscuta epithymum

Cynodon dactylon

Cytisus scoparius

Dactylis glomerata

Danthonia decumbens

Daucus carota

Desmazeria marina

Desmazeria sp.
S5 $\quad$ S11 S15

$\begin{array}{llll}0 & 1 & 1 & \text { Lonicera periclymenum } \\ 1 & 1 & 1 & \text { Lotus corniculatus } \\ 1 & 1 & 1 & \text { Lotus subbiflorus } \\ 0 & 1 & 1 & \text { Malva sylvestris } \\ 1 & 1 & 1 & \text { Medicago lupulina } \\ 0 & 1 & 0 & \text { Mibora minima } \\ 0 & 1 & 0 & \text { Moenchia erecta } \\ 0 & 0 & 1 & \text { Ononis repens } \\ 1 & 1 & 1 & \text { Parapholis incurva } \\ 1 & 0 & 0 & \text { Pedicularis sylvatica } \\ 1 & 0 & 0 & \text { Picris echioides } \\ 1 & 0 & 0 & \text { Plantago coronopus }\end{array}$

Plantago holosteum var. littoralis

Plantago lanceolata

Plantago major

Polygala serpyllifolia

Potentilla erecta

Potentilla reptans

Potentilla sp.

Primula elatior

Prunus spinosa

Puccinellia maritima

Pulicaria dysenterica

Radiola linoides

Romulea columnae

Rosa pimpinellifolia

Rubia peregrina

Rubus sp.

Rumex acetosa

Rumex conglomeratus

Rumex crispus

Rumex sp.

Sagina maritima

Sagina subulata

Salicornia ramosissima

Scilla verna

Sedum acre

Sedum anglicum

Senecio jacobaea

Silene vulgaris ssp. maritima

Solanum dulcamara

Solidago virgaurea ssp. rupicola

Sonchus arvensis
S5 $\quad$ S11 S15

\begin{tabular}{|c|c|}
\hline 1 & 1 \\
\hline & 1 \\
\hline 0 & 1 \\
\hline & 1 \\
\hline & 0 \\
\hline & 1 \\
\hline & 1 \\
\hline & 1 \\
\hline 1 & 1 \\
\hline 1 & 0 \\
\hline 1 & 0 \\
\hline 1 & 1 \\
\hline 0 & 1 \\
\hline 1 & 1 \\
\hline 0 & 0 \\
\hline 1 & 0 \\
\hline 1 & 0 \\
\hline 1 & 0 \\
\hline 0 & 1 \\
\hline 0 & 0 \\
\hline 1 & 0 \\
\hline 1 & 0 \\
\hline 1 & 0 \\
\hline 0 & 1 \\
\hline 0 & 1 \\
\hline 0 & 0 \\
\hline 1 & 0 \\
\hline 1 & 1 \\
\hline 1 & 1 \\
\hline 1 & 0 \\
\hline 1 & 0 \\
\hline 1 & 0 \\
\hline 1 & 1 \\
\hline 0 & 0 \\
\hline 1 & 0 \\
\hline 0 & 1 \\
\hline 0 & 1 \\
\hline 1 & 1 \\
\hline 1 & 1 \\
\hline 1 & 1 \\
\hline 1 & 0 \\
\hline 0 & 0 \\
\hline 1 & 0 \\
\hline
\end{tabular}




\begin{tabular}{|c|c|c|c|c|c|c|}
\hline Elymus repens & 1 & 0 & 0 & Sonchus asper & 1 & 1 \\
\hline Erica ciliaris & 0 & 0 & 1 & Sonchus oleraceus & 0 & 1 \\
\hline Erica cinerea & 1 & 1 & 1 & Spergularia rubra & 1 & 0 \\
\hline Erica vagans & 1 & 0 & 0 & Spergularia rupicola & 1 & 1 \\
\hline Eryngium campestre & 0 & 1 & 0 & Sueda sp. & 0 & 1 \\
\hline Euphorbia portlandica & 0 & 1 & 1 & Tamarix sp. & 1 & 0 \\
\hline Euphrasia sp. & 0 & 0 & 1 & Teucrium scorodonia & 1 & 1 \\
\hline Festuca ovina & 1 & 1 & 1 & Thymus praecox & 0 & 0 \\
\hline Festuca rubra ssp. pruinosa & 1 & 1 & 1 & Trifolium arvense & 0 & 1 \\
\hline Frankenia laevis & 1 & 0 & 0 & Trifolium campestre & 0 & 0 \\
\hline Galium aparine & 0 & 1 & 0 & Trifolium occidentale & 0 & 0 \\
\hline Galium mollugo & 1 & 1 & 0 & Trifolium pratense & 1 & 0 \\
\hline Galium sp. & 0 & 1 & 0 & Trifolium repens & 1 & 0 \\
\hline Genista tinctoria & 1 & 0 & 0 & Ulex europaeus var. maritimus & 1 & 1 \\
\hline Halimione portulacoides & 1 & 0 & 0 & Ulex gallii var. humilis & 0 & 0 \\
\hline Hieracium umbellatum & 0 & 0 & 1 & Umbilicus rupestris & 1 & 1 \\
\hline Holcus lanatus & 1 & 1 & 1 & Vicia hirsuta & 1 & 0 \\
\hline Hyacinthoides non-scripta & 1 & 1 & 0 & Vicia sativa & 1 & 1 \\
\hline Hypochaeris radicata & 1 & 1 & 1 & Viola riviniana & 1 & 0 \\
\hline Inula crithmoides & 1 & 0 & 0 & Viola sp. & 1 & 0 \\
\hline Jasione montana & 0 & 1 & 1 & Vulpia bromoides & 1 & 1 \\
\hline Leontodon saxatilis ssp. saxatilis & 1 & 1 & 1 & & & \\
\hline Limonium vulgare & 1 & 0 & 0 & & & \\
\hline Linum bienne & 0 & 0 & 1 & & & \\
\hline
\end{tabular}


547 Appendix 5. NMDS per site for Spiders and Vegetation. Coloured area corresponding to

548 degradation state. Light grey: Reference; Grey: Mildly degraded; Dark grey: Highly degraded.

549 Figure made with R and ggplot2 package (Wickham 2016).

Spider

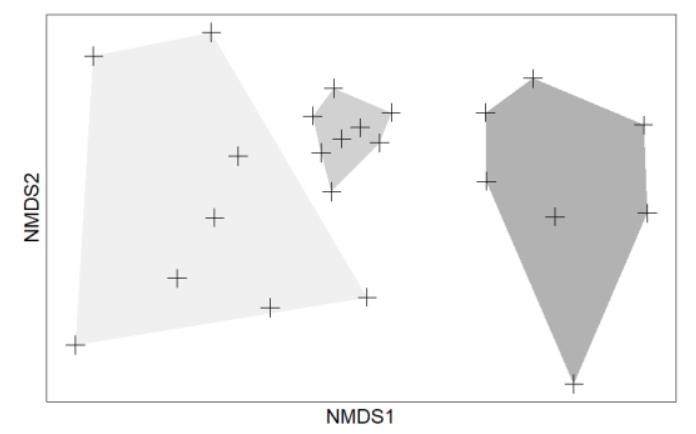

Site 11

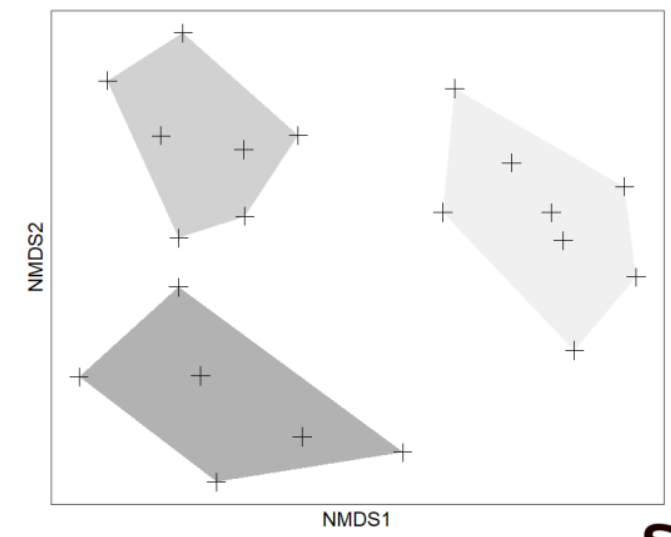

Site 15

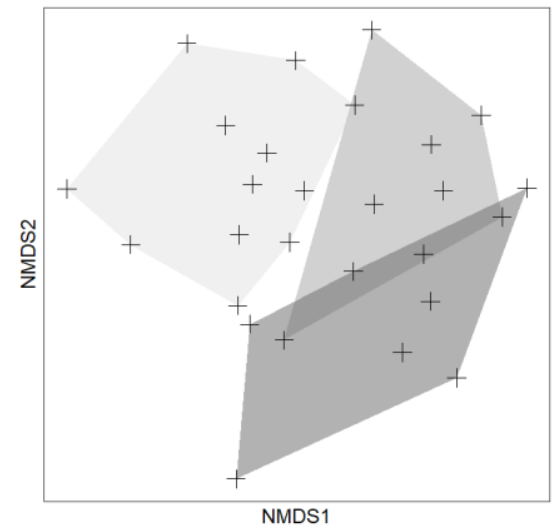

Vegetation
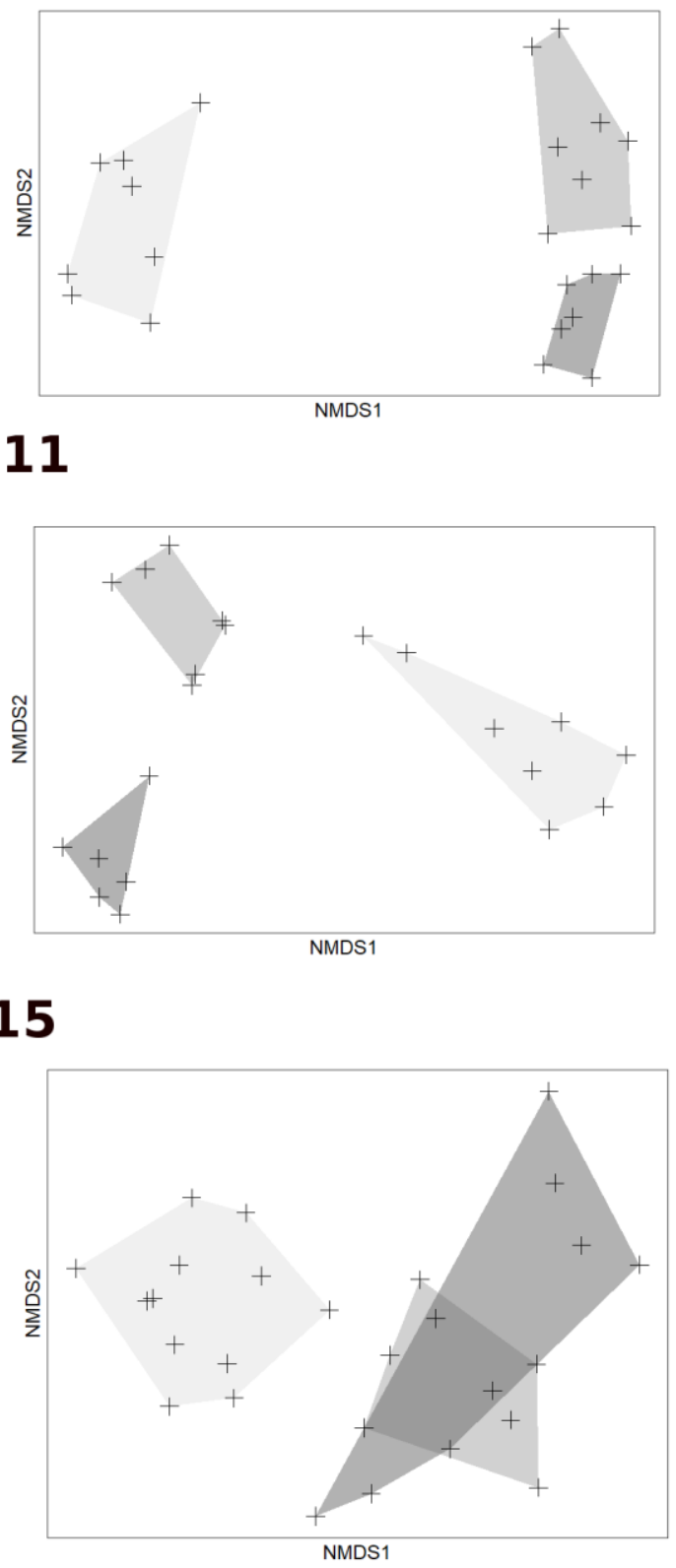